\title{
Genome-wide approaches to understanding human ageing
}

\author{
Matt Kaeberlein \\ Department of Pathology, University of Washington, Seattle, WA 98195, USA \\ Correspondence to: Tel: +1 206616 4523; Fax: +1 206616 3690; E-mail: kaeber@u.washington.edu
}

Date received (in revised form): 6th March 2006

\begin{abstract}
The use of genomic technologies in biogerontology has the potential to greatly enhance our understanding of human ageing. High-throughput screens for alleles correlated with survival in long-lived people have uncovered novel genes involved in age-associated disease. Genome-wide longevity studies in simple eukaryotes are identifying evolutionarily conserved pathways that determine longevity. It is hoped that validation of these 'public' aspects of ageing in mice, along with analyses of variation in candidate human ageing genes, will provide targets for future interventions to slow the ageing process and retard the onset of age-associated pathologies.
\end{abstract}

Keywords: mortality, life span, genomics

\section{Introduction}

The study of the biology of ageing (biogerontology) has seen a reawakening in recent years. Modern molecular techniques are being applied in an effort to understand both the changes that occur as people age and, perhaps more importantly, to identify the genes that determine how quickly these ageassociated changes progress. In addition, as life expectancy has increased in developed nations, an ageing population has contributed to a great societal (and financial) interest in understanding the human ageing process and in ameliorating age-associated physical and cognitive declines.

The genomics revolution, in particular, has begun to have a profound impact on the way that biogerontologists approach the study of ageing. Global gene expression profiling has been used to characterise transcriptional changes associated with age and longevity, as discussed in several recent reviews. ${ }^{1-6}$ Proteomics and metabolomics technologies are also now being applied to ageing-related problems ${ }^{7,8}$ and, as these technologies continue to mature, will certainly be used more extensively. One particularly important application of these technologies will be the identification of diagnostic biomarkers of ageing and ageing rate. ${ }^{9-12}$

This review will describe the use of genomics methods to identify genes that influence human ageing. Two types of approaches will be discussed: genome-wide studies of allelic variants that correlate with longevity in people and highthroughput life span studies in lower eukaryotes. The synthesis of these approaches is beginning to uncover highly conserved aspects of the ageing process and to identify candidate gene targets for future intervention into human ageing and age-associated disease.

\section{Searching for allelic variants that determine longevity in humans}

The long life span enjoyed by most people presents a difficulty for researchers wishing to study the genetic and environmental factors that influence ageing and age-associated disease in people. The lack of accepted biomarkers of ageing rate means that there is no diagnostic test which can be used to determine whether a particular mutation or environmental change is likely to have an impact on longevity. ${ }^{13}$ The search for such biomarkers is an ongoing process. For now, however, alternative, methods are being developed to address these questions.

One approach for identifying genetic features that influence longevity is the study of individuals that achieve extreme longevity. ${ }^{14,15}$ Centenarians represent just such a group, with approximately 1 in 10,000 people reaching their 100th birthday. ${ }^{16}$ There is substantial evidence that genetic components influence human longevity and that centenarians are people who have escaped the common age-associated diseases which account for a large fraction of the mortality in the overall population. ${ }^{15,17,18}$ In a pioneering effort to identify genetic polymorphisms over-represented among centenarians, Puca and colleagues used linkage analysis to scan the genomes of 308 individuals belonging to 137 sibships displaying extreme longevity. ${ }^{19}$ From this analysis, significant linkage 
was noted for a locus on chromosome $4,{ }^{19}$ which was subsequently mapped to the gene coding for microsomal triglyceride transfer protein $(M T P) .{ }^{20}$ Alleles of MTP are associated with abetalipoproteinaemia and familial hypobetalipoproteinaemia in humans. ${ }^{21,22}$ It therefore seems likely that the longevity-associated allele identified by Puca and colleagues represents an allele that is protective against heart disease. ${ }^{20}$

An alternative to studying extremely long-lived cohorts is to identify genetic polymorphisms that change in frequency across a population as a function of age. For example, a highthroughput single nucleotide polymorphism (SNP)-typing approach — where allele frequencies are determined for a large number of SNPs from individuals of many different ages has the potential to uncover alleles that influence longevity. Under such a design, alleles that result in disease susceptibility should decrease in frequency with donor age, while alleles that are important for longevity should increase in frequency. This approach was used successfully to identify an isoleucine to valine polymorphism in the protein kinase A (PKA) anchoring protein AKAP2, which correlates with decreased longevity and cardiac disease. ${ }^{23}$ PKA activity has been linked to ageing in simple eukaryotes. ${ }^{10,24-26}$ Mice with altered levels of PKA have phenotypes consistent with an ageing-related role, such as decreased adipose tissue, protection against obesity and elevated expression of uncoupling proteins. ${ }^{27-29}$ Surprisingly, no additional large-scale searches for age-related changes in SNP frequencies have been described. As technologies for SNP discovery and quantitative analysis continue to improve, this approach may warrant further attention.

\section{Difficulties in using humans to study human longevity}

Both examples of age-correlated polymorphisms highlighted above (AKAP2 and MTP) demonstrate one of the difficulties associated with identifying genes that influence the rate of ageing from genetic studies of longevity in people: the profound effect of a relatively small number of age-associated diseases on human mortality. A majority of deaths in developed nations occur as a result of a relatively small number of age-associated diseases, including cardiovascular disease, cancer, stroke and diabetes. Thus, one of the prerequisites for achieving extreme longevity is a reduced risk for these diseases, and polymorphisms conferring reduced risk to one or more of these diseases can have a significant effect on individual longevity. In the examples of MTP and $A K A P 2$, the observed effects on longevity are almost certainly due to an altered risk of cardiovascular disease. ${ }^{20,23}$ Does this mean that individuals with the longevity-associated allele of MTP are ageing more slowly? Not necessarily. The risk for one or more age-associated phenotypes is reduced; however, there is no evidence that many or all age-associated phenotypes are also retarded in such individuals. Other alleles have also been correlated with life span in people (Table 1), and in almost every case can be attributed to delayed onset of one, or a few, age-associated disease(s).

A second difficulty in population-based studies of human longevity is controlling for population-specific factors. ${ }^{50}$ For example, the prevalence of specific age-associated diseases is variable in different populations. This can be due to any combination of cultural (eg diet), historical (eg famine), environmental (eg exposure to toxic chemicals) or genetic components, and can have a profound impact on the types of genotypic variants that influence survival to old age. Recently, it has been suggested the role of MTP as a longevity-related locus may be specific for the cohort used in the study from which it was initially identified. ${ }^{50,51}$ Simply designing an appropriately controlled human longevity study is challenging, and care must be taken to avoid population stratification. Thus, it will be important to test any candidate human longevity locus in multiple populations to determine the generality of the correlation.

A third potential barrier to identifying genetic variants that have a significant impact on human ageing may be that such variants carry a large selective disadvantage and have been culled from the gene pool. To date, no genetic variant has been definitively shown to slow the rate of human ageing, although rare mutations can accelerate at least some aspects of the ageing process, resulting in progeria syndromes. ${ }^{52}$ Abundant evidence from model organisms, however, suggests that mutations in single genes can dramatically slow the rate of ageing and the onset of many (perhaps all) age-associated phenotypes. On the surface, it may seem surprising that, if such 'master regulators' of ageing exist in people, no alleles have been identified that confer extreme longevity. The examples from simpler eukaryotes, however, also demonstrate quite clearly that these types of mutations often come with significant fitness and reproductive costs. ${ }^{53-55}$ Thus, strong longevity-enhancing alleles in genes that influence ageing rate are likely to have been selected against during recent human evolution, perhaps making their detection by largescale polymorphism studies impossible.

\section{Genome-wide approaches to identifying 'public' pathways of ageing}

The use of model systems for ageing-related research provides an avenue for getting around many of the difficulties associated with human studies. Both mice and rats are commonly-used mammalian models for ageing and longevity studies. Several simple eukaryotic models have also been developed, including the budding yeast Saccharomyces cerevisiae, the nematode Caenorhabditis elegans and the fruit fly Drosophila melanogaster. ${ }^{56}$ Perhaps the greatest advantage afforded by model 
Table I. Selected genes for which polymorphisms have been reported to correlate with human longevity. Obvious life spanshortening disease alleles have been excluded. It should be noted that, in many cases, the reported correlation with longevity has been disputed by subsequent work.

\begin{tabular}{|c|c|c|}
\hline Gene & Gene function & Reference \\
\hline 3' APOB-VNTR & Apolipoprotein B & 30 \\
\hline $5 H T T$ & Serotonin transporter & 31 \\
\hline$A C E$ & $\begin{array}{l}\text { Angiotensin-converting } \\
\text { enzyme }\end{array}$ & 32 \\
\hline$A P O E$ & Apolipoprotein E & 32 \\
\hline CETP & $\begin{array}{l}\text { Cholesteryl ester transfer } \\
\text { protein }\end{array}$ & 33,34 \\
\hline GHI & Growth hormone & 35 \\
\hline IGF-IR & $\begin{array}{l}\text { Insulin-like growth factor } \\
\text { (IGF)-I receptor }\end{array}$ & 36 \\
\hline IL-IO & Interleukin 10 & 37 \\
\hline KLOTHO & $\begin{array}{l}\text { Insulin/IGF-I-repressing } \\
\text { hormone }\end{array}$ & $38-40$ \\
\hline MTND2 & $\begin{array}{l}\text { Mitochondrial NADH } \\
\text { dehydrogenase }\end{array}$ & 41 \\
\hline MTP & $\begin{array}{l}\text { Microsomal triglyceride } \\
\text { transfer protein }\end{array}$ & 20 \\
\hline $\mathrm{NR3Cl}$ & Glucocorticoid receptor & 42 \\
\hline PI3KCB & $\begin{array}{l}\text { Phosphatidylinositol 3-kinase } \\
\text { catalytic subunit }\end{array}$ & 36 \\
\hline PPARG & $\begin{array}{l}\text { Peroxisome proliferator- } \\
\text { activated } \\
\text { receptor gamma } 2\end{array}$ & 43 \\
\hline $\mathrm{SHCl}$ & SHC-transforming protein I & 44 \\
\hline SIRT3 & Sirtuin protein deacetylase & 45 \\
\hline $\mathrm{TH}$ & Tyrosine hydroxylase & 46 \\
\hline TLR4 & Toll-like receptor 4 & 47 \\
\hline TP53 & Tumour suppressor p53 & 48,49 \\
\hline
\end{tabular}

Abbreviations: $\mathrm{NADH}=$ the reduced form of nicotinamide adenine dinucleotide; $\mathrm{SHC}=$ Src homology 2 domain-containing.

organisms for ageing-related studies is that the relatively short life spans of these organisms allows for controlled longevity studies to determine whether a particular mutation or environmental change alters ageing rate. In particular, interventions that increase population life span are of interest because they either slow the rate of ageing, delay the onset
Table 2. Potential conserved determinants of longevity. Genes shown have been reported to increase life span when mutated in more than one organism.

\begin{tabular}{|l|l|}
\hline Gene family & Description \\
\hline Catalase & $\begin{array}{l}\text { Increased catalase activity increases life } \\
\text { span in yeast }\end{array}$ and mice $^{63}$
\end{tabular}

of ageing or both. Several dozen single-gene mutations that significantly increase life span have been identified from studies in model organisms. ${ }^{57}$ More recently, genome-wide screens for longevity have been carried out in both yeast and worms, resulting in a wealth of data and a better understanding of the degree to which the genetic basis of ageing has been conserved.

A question that is often raised when considering the usefulness of model organisms in ageing research is whether the ageing process has been sufficiently evolutionarily conserved that the mechanisms of ageing are shared between lower eukaryotes and people, or even between non-human mammals and people. While this question is impossible to answer at this time, there is reason to think that at least some aspects of ageing are highly conserved. ${ }^{58-60}$ For example, all of the model organisms used for ageing-related research display an approximately exponential increase in mortality with age (Gompertz-Makeham-like mortality), consistent with the idea that important aspects of the underlying ageing process is conserved. ${ }^{61}$ Perhaps the most compelling reason to think that ageing is highly conserved is the recent identification of several conserved determinants of longevity — orthologous genes (or similar environmental changes) that determine ageing rate in evolutionarily divergent organisms (Table 2). These conserved longevity determinants are likely to regulate 'public mechanisms of ageing ${ }^{\text {, }}{ }^{4}$ that have been maintained 
through evolution and which determine longevity in response to environmental cues, such as nutrient availability.

\section{Genome-wide studies of ageing in worms}

C. elegans has proven to be one of the most important model organisms for ageing-related research, providing the first wellcharacterised model for the role of insulin/insulin-like growth factor I (IGF-1) in ageing. Several components of this pathway have been shown to regulate longevity in worms, including an insulin-like receptor (Daf-2) ${ }^{64,65}$ a phosphatidylinositol 3-kinase (Age-1), ${ }^{85,86}$ proteins orthologous to Akt

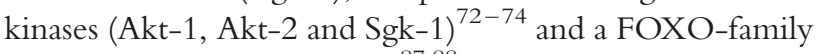
transcription factor (Daf-16). ${ }^{87,88}$ Global gene expression profiling by microarray has further elucidated some of the downstream components of this pathway, which are involved in antimicrobial, oxidative and other stress responses. ${ }^{89,90}$

The true power of C. elegans as a model for ageing-related research has become apparent with the development of RNA interference (RNAi) as a technology for gene expression knock-down in worms. The typical food source provided to C. elegans is live Escherichia coli grown on a solid medium. E. coli expressing a plasmid-encoded double-stranded RNA corresponding to a $C$. elegans open reading frame (ORF) knocks down expression of the targeted gene. ${ }^{91}$ An RNAi library corresponding to 17,000 unique genes $(\sim 85$ per cent of C. elegans ORFs) has been constructed, ${ }^{92}$ and two independent genome-wide RNAi screens have been carried out for genes that influence longevity in worms. ${ }^{73,93-95}$ Genes that increase life span when knocked down can be grouped into functional categories, the largest being genes important for mitochondrial respiration and genes involved in insulin/IGF-I signalling. Several uncharacterised genes were identified as well, suggesting that important aspects of the ageing process remain uncharacterised, even in simple eukaryotes.

\section{A multi-organism approach to identifying public pathways regulating longevity}

Recently, a genomic approach to uncovering genetic determinants of longevity that have been conserved from yeast to mammals has been described, based on the hypothesis that protein families which function to determine ageing rate in both yeast and worms are likely to play a similar role in mammals. ${ }^{10,96}$ The first phase of this proposal involves genomic analysis of ageing in yeast. ${ }^{97}$ Two types of ageing are commonly studied in yeast: replicative life span, which refers to the number of times a yeast cell can divide prior to senescence, ${ }^{98}$ and chronological life span, measured by the length of time a cell can survive in a non-dividing state. ${ }^{99}$ High- throughput assays for both replicative and chronological ageing have been developed, ${ }^{26,100}$ which will allow for life span determination of approximately 4,800 single-gene deletion strains contained in the yeast ORF deletion collection. ${ }^{101}$

For each yeast ageing gene identified from these screens, the homologous genes in C. elegans (if any) will be examined by measuring life span in response to RNAi-mediated knockdown. Those orthologue pairs that determine longevity in both yeast and C. elegans will then be candidates for further study in a mammalian system. Conditional and tissue specific knockout of mouse genes orthologous to conserved yeast and C. elegans ageing genes will be carried out and selected lines subjected to life span analysis. Due to the costly nature of rodent longevity studies, this is an exceptional method for identifying high-interest candidates. Clearly, any gene family found to determine life span in yeast, worms and mice will be of great interest as a likely determinant of human longevity.

Even prior to life span studies in mice, the identification of longevity determinants conserved in simple eukaryotes, such as yeast and worms, will allow for SNP analysis of human orthologues to determine whether there is a correlation of certain alleles with longevity or age-associated disease. For example, increased expression of Sir2-family proteins increases life span in yeast, ${ }^{75}$ worms ${ }^{76}$ and flies, ${ }^{77}$ and alleles of a human homolog, SIRT3, are reported to correlate with longevity in people $^{78}$ (Table 1). Likewise, mutation of the insulin/IGF-I receptor homologues increase life span in worms ${ }^{64,65}$ and flies, ${ }^{66}$ and it has been suggested that allelic variants in the human IGF-I receptor correlate with longevity. ${ }^{36}$ The nutrient-responsive kinases TOR (target of rapamycin), PKA and Sch9/Akt represent additional high-interest candidates, for which human longevity data have not been reported. More subtle effects on human ageing, which may be masked by disease alleles in genome-wide scans, can potentially be uncovered by this type of targeted approach based on knowledge gleaned from model organisms.

\section{Conclusion}

The further development and application of genomics methods toward biogerontology has the potential to dramatically enhance understanding of human ageing. Genomic approaches have already uncovered genes important in the onset of human age-associated disease. In simpler eukaryotes, genome-wide studies are rapidly providing a detailed picture of the molecular pathways that regulate ageing. The most effective future studies may come from combining the genes identified in simpler organisms with technologies to rapidly uncover allelic variation in human orthologues which may influence longevity and disease. There is ample reason for optimism that these approaches will enhance our understanding of the molecular biology of ageing and, ultimately, our ability to treat age-associated disease. 


\section{References}

1. Vijg, J. and Calder, R.B. (2004), 'Transcripts of aging', Trends Genet. Vol. 20, pp. 221-224.

2. Weindruch, R., Kayo, T., Lee, C.K. and Prolla, T.A. (2001), 'Microarray profiling of gene expression in aging and its alteration by caloric restriction in mice', J. Nutr. Vol. 131, pp. 918S-923S

3. Prolla, T.A. (2005), 'Multiple roads to the aging phenotype: insights from the molecular dissection of progerias through DNA microarray analysis', Mech. Ageing Dev. Vol. 126, pp. 461-465.

4. Melov, S. and Hubbard, A. (2004), 'Microarrays as a tool to investigate the biology of aging: A retrospective and a look to the future', Sci. Aging Knowledge Environ. Available at http://sageke.sciencemag.org/cgi/ content/full/2004/42/re7.

5. Kaeberlein, M. (2006), 'Application of high-throughput technologies to aging-related research', in Conn, P.M., (Ed.), Handbook of models for human aging, Elsevier Academic Press, Boston, MA.

6. Hudson, F.N., Kaeberlein, M., Linford, N. et al. (2005), 'Microarray analysis of gene expression changes in aging', in: Austad, S.N., (Ed.), Handbook of the biology of aging, Academic Press, Boston, MA.

7. Schoneich, C. (2005), 'Mass spectrometry in aging research', Mass Spectrom. Rev. Vol. 24, pp. 701-718.

8. Schoneich, C. (2003), 'Proteomics in gerontological research', Exp Gerontol. Vol. 38, pp. 473-481.

9. Dhahbi, J.M., Kim, H.J., Mote, P.L. et al. (2004), 'Temporal linkage between the phenotypic and genomic responses to caloric restriction', Proc. Natl. Acad. Sci. USA Vol. 101, pp. 5524-5529.

10. Kaeberlein, M. (2004), 'Aging-related research in the "-omics" age', Sci. Aging Knowledge Environ. Available at http://sageke.sciencemag.org/ cgi/content/full/2004/42/pe39.

11. Butler, R.N., Sprott, R., Warner, H. et al. (2004), 'Biomarkers of aging: From primitive organisms to humans', J. Gerontol. A Biol. Sci. Med. Sci. Vol. 59, pp. B560-567.

12. Park, S.K. and Prolla, T.A. (2005), 'Lessons learned from gene expression profile studies of aging and caloric restriction', Ageing Res. Rev. Vol. 4 , pp. $55-65$.

13. Warner, H.R. (2004), 'Current status of efforts to measure and modulate the biological rate of aging', J. Gerontol. A Biol. Sci. Med. Sci. Vol. 59 , pp. 692-696.

14. Franceschi, C. and Bonafe, M. (2003), 'Centenarians as a model for healthy aging', Biochem. Soc. Trans. Vol. 31, pp. 457-461.

15. Perls, T., Kunkel, L. and Puca, A. (2002), 'The genetics of aging', Curr. Opin. Genet. Dev. Vol. 12, pp. 362-369.

16. Perls, T.T., Bochen, K., Freeman, M. et al. (1999), 'Validity of reported age and centenarian prevalence in New England', Age Ageing Vol. 28, pp. 193-197.

17. Hitt, R., Young-Xu, Y., Silver, M. and Perls, T. (1999), 'Centenarians: The older you get, the healthier you have been', Lancet Vol. 354, p. 652.

18. Andersen, S.L., Terry, D.F., Wilcox, M.A. et al. (2005), 'Cancer in the oldest old', Mech. Ageing Dev. Vol. 126, pp. 263-267.

19. Puca, A.A., Daly, M.J., Brewster, S.J. et al. (2001), 'A genome-wide scan for linkage to human exceptional longevity identifies a locus on chromosome 4', Proc. Natl. Acad. Sci. USA Vol. 98, pp. 10505-10508.

20. Geesaman, B.J., Benson, E., Brewster, S.J. et al. (2003), 'Haplotype-based identification of a microsomal transfer protein marker associated with the human lifespan', Proc. Natl. Acad. Sci. USA Vol. 100, pp. 14115-14120.

21. Gregg, R.E. and Wetterau, J.R. (1994), 'The molecular basis of abetalipoproteinemia', Curr. Opin. Lipidol. Vol. 5, pp. 81-86.

22. Di Leo, E., Lancellotti, S., Penacchioni, J.Y. et al. (2005), 'Mutations in MTP gene in abeta- and hypobeta-lipoproteinemia', Atherosclerosis Vol. 180, pp. 311-318.

23. Kammerer, S., Burns-Hamuro, L.L., Ma, Y. et al. (2003), 'Amino acid variant in the kinase binding domain of dual-specific A kinase-anchoring protein 2: A disease susceptibility polymorphism', Proc. Natl. Acad. Sci. USA Vol. 100, pp. 4066-4071.

24. Lin, S.J., Defossez, P.A. and Guarente, L. (2000), 'Requirement of NAD and SIR 2 for life-span extension by calorie restriction in Saccharomyces cerevisiae', Science Vol. 289, pp. 2126-2128.
25. Fabrizio, P., Pozza, F., Pletcher, S.D. et al. (2001), 'Regulation of longevity and stress resistance by Sch9 in yeast', Science Vol. 292, pp. $288-290$

26. Kaeberlein, M., Powers, R.W., Steffen, K.K. et al. (2005), 'TOR and Sch9 determine yeast replicative life span in response to nutrients', Science Vol. 310, pp. 1193-1196.

27. Nolan, M.A., Sikorski, M.A. and McKnight, G.S. (2004), 'The role of uncoupling protein 1 in the metabolism and adiposity of RII beta-protein kinase A-deficient mice', Mol. Endocrinol. Vol. 18, pp. 2302-2311.

28. Cummings, D.E., Brandon, E.P., Planas, J.V. et al. (1996), 'Genetically lean mice result from targeted disruption of the RII beta subunit of protein kinase A', Nature Vol. 382, pp. 622-626.

29. Newhall, K.J., Cummings, D.E., Nolan, M.A. and McKnight, G.S (2005), 'Deletion of the RIIbeta-subunit of protein kinase A decreases body weight and increases energy expenditure in the obese, leptindeficient ob/ob mouse', Mol. Endocrinol. Vol. 19, pp. 982-991.

30. Garasto, S., Berardelli, M., DeRango, F. et al. (2004), 'A study of the average effect of the 3 'APOB-VNTR polymorphism on lipidemic parameters could explain why the short alleles $(<35$ repeats) are rare in centenarians', BMC Med. Genet. Vol. 5, p. 3

31. Gondo, Y., Hirose, N., Arai, Y. et al. (2005), 'Contribution of an affect-associated gene to human longevity: Prevalence of the long-allele genotype of the serotonin transporter-linked gene in Japanese centenarians', Mech. Ageing Dev. Vol. 126, pp. 1178-1184.

32. Schachter, F., Faure-Delanef, L., Guenot, F. et al. (1994), 'Genetic associations with human longevity at the APOE and ACE loci', Nat. Genet. Vol. 6, pp. 29-32.

33. Barzilai, N., Atzmon, G., Schechter, C. et al. (2003), 'Unique lipoprotein phenotype and genotype associated with exceptional longevity', JAMA Vol. 290, pp. 2030-2040.

34. Atzmon, G., Rincon, M., Rabizadeh, P. and Barzilai, N. (2005), 'Biological evidence for inheritance of exceptional longevity', Mech. Ageing Dev. Vol. 126, pp. 341-345.

35. van Heemst, D., Beekman, M., Mooijaart, S.P. et al. (2005), 'Reduced insulin/IGF-1 signalling and human longevity', Aging Cell Vol. 4 pp. $79-85$.

36. Bonafe, M., Barbieri, M., Marchegiani, F. et al. (2003), 'Polymorphic variants of insulin-like growth factor I (IGF-I) receptor and phosphoinositide 3-kinase genes affect IGF-I plasma levels and human longevity: Cues for an evolutionarily conserved mechanism of life span control', J. Clin. Endocrinol. Metab. Vol. 88, pp. 3299-3304.

37. Lio, D., Candore, G., Crivello, A. et al. (2004), 'Opposite effects of interleukin 10 common gene polymorphisms in cardiovascular diseases and in successful ageing: Genetic background of male centenarians is protective against coronary heart disease', J. Med. Genet. Vol. 41, pp. $790-794$

38. Kurosu, H., Yamamoto, M., Clark, J.D. et al. (2005), 'Suppression of aging in mice by the hormone Klotho', Science Vol. 309, pp. 1829-1833.

39. Arking, D.E., Atzmon, G., Arking, A. et al. (2005), 'Association between a functional variant of the KLOTHO gene and high-density lipoprotein cholesterol, blood pressure, stroke, and longevity', Circ. Res. Vol. 96, pp. $412-418$

40. Arking, D.E., Krebsova, A., Macek, M. et al. (2002), 'Association of human aging with a functional variant of klotho', Proc. Natl. Acad. Sci. USA Vol. 99, pp. 856-861.

41. Tanaka, M., Gong, J.S., Zhang, J. et al. (1998), 'Mitochondrial genotype associated with longevity', Lancet Vol. 351, pp. 185-186.

42. van Rossum, E.F., Feelders, R.A., van den Beld, A.W. et al. (2004), 'Association of the ER22/23EK polymorphism in the glucocorticoid receptor gene with survival and C-reactive protein levels in elderly men', Am. J. Med. Vol. 117, pp. 158-162.

43. Barbieri, M., Bonafe, M., Rizzo, M.R. et al. (2004), 'Gender specific association of genetic variation in peroxisome proliferator-activated receptor (PPAR)gamma-2 with longevity', Exp. Gerontol. Vol. 39, pp. $1095-1100$

44. Mooijaart, S.P., van Heemst, D., Schreuder, J. et al. (2004), 'Variation in the SHC1 gene and longevity in humans', Exp. Gerontol. Vol. 39, pp. 263-268 
45. Rose, G., Dato, S., Altomare, K. et al. (2003), 'Variability of the SIRT3 gene, human silent information regulator Sir2 homologue, and survivorship in the elderly', Exp. Gerontol. Vol. 38, pp. 1065-1070

46. De Benedictis, G., Carotenuto, L., Carrieri, G. et al. (1998), 'Gene/ longevity association studies at four autosomal loci (REN, THO, PARP, SOD2)', Eur. J. Hum. Genet. Vol. 6, pp. 534-541.

47. Balistreri, C.R., Candore, G., Colonna-Romano, G. et al. (2004), 'Role of Toll-like receptor 4 in acute myocardial infarction and longevity', JAMA Vol. 292, pp. 2339-2340.

48. Gaspari, L., Pedotti, P., Bonafe, M. et al. (2003), 'Metabolic gene polymorphisms and 553 mutations in healthy centenarians and younger controls', Biomarkers Vol. 8, pp. 522-528.

49. van Heemst, D., Mooijaart, S.P., Beekman, M. et al. (2005), 'Variation in the human TP53 gene affects old age survival and cancer mortality', Exp. Gerontol. Vol. 40, pp. 11-15.

50. Nebel, A. and Schreiber, S. (2005), 'Allelic variation and human longevity', Sci. Aging Knowledge Environ. Available at http:// sageke.sciencemag.org/cgi/content/full/2005/29/pe23.

51. Nebel, A., Croucher, P.J., Stiegeler, R. et al. (2005), 'No association between microsomal triglyceride transfer protein (MTP) haplotype and longevity in humans', Proc. Natl. Acad. Sci. USA Vol. 102, pp. 7906-7909.

52. Smith, E.D., Kudlow, B.A., Frock, R.L. and Kennedy, B.K. (2005), 'A-type nuclear lamins, progerias and other degenerative disorders', Mech. Ageing Dev. Vol. 126, pp. 447-460.

53. Buck, S., Vettraino, J., Force, A.G. and Arking, R. (2000), 'Extended longevity in Drosophila is consistently associated with a decrease in developmental viability', J. Gerontol. A Biol. Sci. Med. Sci. Vol. 55, pp. B292-B301.

54. Jenkins, N.L., McColl, G. and Lithgow, G.J. (2004), 'Fitness cost of extended lifespan in Caenorhabditis elegans', Proc. Biol. Sci. Vol. 271 pp. $2523-2526$.

55. Tissenbaum, H.A. and Ruvkun, G. (1998), 'An insulin-like signaling pathway affects both longevity and reproduction in Caenorhabditis elegans', Genetics Vol. 148, pp. 703-717.

56. Finch, C.E. and Ruvkun, G. (2001), 'The genetics of aging', Annu. Rev Genomics Hum. Genet. Vol. 2, pp. 435-462.

57. Kaeberlein, M., Jegalian, B. and McVey, M. (2002), 'AGEID: A database of aging genes and interventions', Mech. Ageing Dev. Vol. 123, pp. 1115-1119.

58. Guarente, L. and Kenyon, C. (2000), 'Genetic pathways that regulate ageing in model organisms', Nature Vol. 408, pp. 255-262.

59. Kenyon, C. (2005), 'The plasticity of aging: Insights from long-lived mutants', Cell Vol. 120, pp. 449-460.

60. Miller, R.A. (2005), 'Genetic approaches to the study of aging', J. Am. Geriatr. Soc. Vol. 53, pp. S284-S286.

61. Kaeberlein, M., McVey, M. and Guarente, L. (2001), 'Using yeast to discover the fountain of youth', Sci. Aging Knowledge Environ. Available at http://sageke.sciencemag.org/cgi/conent/full/2001/1/pe1

62. Fabrizio, P., Liou, L.L., Moy, V.N. et al. (2003), 'SOD2 functions downstream of Sch9 to extend longevity in yeast', Genetics Vol. 163, pp. 35-46.

63. Schriner, S.E., Linford, N.J., Martin, G.M. et al. (2005), 'Extension of murine life span by overexpression of catalase targeted to mitochondria', Science Vol. 308, pp. 1909-1911.

64. Kenyon, C., Chang, J., Gensch, E. et al. (1993), 'A C. elegans mutant that lives twice as long as wild type', Nature Vol. 366, pp. 461-464.

65. Kimura, K.D., Tissenbaum, H.A., Liu, Y. and Ruvku, G. (1997), 'daf-2, an insulin receptor-like gene that regulates longevity and diapause in Caenorhabditis elegans', Science Vol. 277, pp. 942-946.

66. Tatar, M., Kopelman, A., Epstein, D. et al. (2001), 'A mutant Drosophila insulin receptor homolog that extends life-span and impairs neuroendocrine function', Science Vol. 292, pp. 107-110.

67. Holzenberger, M., Dupont, J., Ducos, B. et al. (2003), 'IGF-1 receptor regulates lifespan and resistance to oxidative stress in mice', Nature Vol. 421, pp. 182-187.

68. Bluher, M., Patti, M.E., Gesta, S. et al. (2004), 'Intrinsic heterogeneity in adipose tissue of fat-specific insulin receptor knock-out mice is associated with differences in patterns of gene expression', J. Biol. Chem. Vol. 279, pp. 31891-31901.

69. Chang, K.T. and Min, K.T. (2002), 'Regulation of lifespan by histone deacetylase', Ageing Res. Rev. Vol. 1, pp. 313-326.

70. Rogina, B., Helfand, S.L. and Frankel, S. (2002), 'Longevity regulation by Drosophila Rpd3 deacetylase and caloric restriction', Science Vol. 298, p. 1745.

71. Kaeberlein, M. and Kennedy, B.K. (2005), 'Large-scale identification in yeast of conserved ageing genes', Mech. Ageing Dev. Vol. 126, pp. $17-21$.

72. Hertweck, M., Gobel, C. and Baumeister, R. (2004), 'C. elegans SGK-1 is the critical component in the Akt/PKB kinase complex to control stress response and life span', Dev. Cell Vol. 6, pp. 577-588.

73. Hamilton, B., Dong, Y., Shindo, M. et al. (2005), 'A systematic RNAi screen for longevity genes in C. elegans', Genes Dev. Vol. 19, pp. 1544-1555.

74. Oh, S.W., Mukhopadhyay, A., Svrzikapa, N. et al. (2005), 'JNK regulates lifespan in Caenorhabditis elegans by modulating nuclear translocation of forkhead transcription factor/DAF-16', Proc. Natl. Acad. Sci. USA Vol. 102, pp. 4494-4499.

75. Kaeberlein, M., McVey, M. and Guarente, L. (1999), 'The SIR2/3/4 complex and SIR 2 alone promote longevity in Saccharomyces cerevisiae by two different mechanisms', Genes Dev. Vol. 13, pp. 2570-2580.

76. Tissenbaum, H.A. and Guarente, L. (2001), 'Increased dosage of a sir-2 gene extends lifespan in Caenorhabditis elegans', Nature Vol. 410 , pp. $227-230$.

77. Rogina, B. and Helfand, S.L. (2004), 'Sir2 mediates longevity in the fly through a pathway related to calorie restriction', Proc. Natl. Acad. Sci. USA Vol. 101, pp. 15998-16003.

78. Bellizzi, D., Rose, G., Cavalcante, P. et al. (2005), 'A novel VNTR enhancer within the SIRT3 gene, a human homologue of SIR2, is associated with survival at oldest ages', Genomics Vol. 85, pp. 258-263.

79. Phillips, J.P., Parkes, T.L. and Hilliker, A.J. (2000), 'Targeted neuronal gene expression and longevity in Drosophila', Exp. Gerontol. Vol. 35, pp. 1157-1164.

80. Powers, 3rd, R.W., Kaeberlein, M., Caldwell, S.D. et al. (2006), 'Extension of chronological life span in yeast by decreased TOR pathway signaling', Genes Dev. Vol. 20, pp. 174-184

81. Jia, K., Chen, D. and Riddle, D.L. (2004), 'The TOR pathway interacts with the insulin signaling pathway to regulate C. elegans larval development, metabolism and life span', Development Vol. 131, pp. 3897-3906.

82. Vellai, T., Takacs-Vellai, K., Zhang, Y. et al. (2003), 'Genetics: Influence of TOR kinase on lifespan in C. elegans', Nature Vol. 426, p. 620.

83. Kapahi, P., Zid, B.M., Harper, T. et al. (2004), 'Regulation of lifespan in Drosophila by modulation of genes in the TOR signaling pathway', Curr. Biol. Vol. 14, pp. 885-890.

84. Martin, G.M. (1988), 'Constitutional genetic markers of aging', Exp. Gerontol. Vol. 23, pp. 257-270.

85. Morris, J.Z., Tissenbaum, H.A. and Ruvkun, G. (1996), 'A phosphatidylinositol-3-OH kinase family member regulating longevity and diapause in Caenorhabditis elegans', Nature Vol. 382, pp. 536-539.

86. Friedman, D.B. and Johnson, T.E. (1988), 'A mutation in the age-1 gene in Caenorhabditis elegans lengthens life and reduces hermaphrodite fertility', Genetics Vol. 118, pp. 75-86.

87. Lin, K., Dorman, J.B., Rodan, A. and Kenyon, C. (1997), 'daf-16: An HNF-3/forkhead family member that can function to double the life-span of Caenorhabditis elegans', Science Vol. 278, pp. 1319-1322.

88. Ogg, S., Paradis, S., Gottlieb, S. et al. (1997), 'The Fork head transcription factor DAF-16 transduces insulin-like metabolic and longevity signals in C. elegans', Nature Vol. 389, pp. 994-999.

89. McElwee, J., Bubb, K. and Thomas, J.H. (2003), 'Transcriptional outputs of the Caenorhabditis elegans forkhead protein DAF-16', Aging Cell Vol. 2, pp. 111-121.

90. Murphy, C.T., McCarroll, S.A., Bargmann, C.I. et al. (2003), 'Genes that act downstream of DAF-16 to influence the lifespan of Caenorhabditis elegans', Nature Vol. 424, pp. 277-283.

91. Kamath, R.S. and Ahringer, J. (2003), 'Genome-wide RNAi screening in Caenorhabditis elegans', Methods Vol. 30, pp. 313-321. 
92. Kamath, R.S., Fraser, A.G., Dong, Y. et al. (2003), 'Systematic functional analysis of the Caenorhabditis elegans genome using RNAi', Nature Vol. 421, pp. 231-237.

93. Hansen, M., Hsu, A.L., Dillin, A. and Kenyon, C. (2005), 'New genes tied to endocrine, metabolic, and dietary regulation of lifespan from a Caenorhabditis elegans genomic RNAi screen', PLoS Genet. Vol. 1, pp. $119-128$.

94. Dillin, A., Hsu, A.L., Arantes-Oliveira, N. et al. (2002), 'Rates of behavior and aging specified by mitochondrial function during development', Science Vol. 298, pp. 2398-2401.

95. Lee, S.S., Lee, R.Y., Fraser, A.G. et al. (2003), 'A systematic RNAi screen identifies a critical role for mitochondria in C. elegans longevity', Nat. Genet. Vol. 33, pp. 40-48.

96. Consortium for the determination of public pathways regulating longevity, University of Washington, Seattle, WA. Available at http://www.pathology.washington.edu/research/bioage/ellison. [cited May 11, 2006].

97. Kaeberlein, M., McDonagh, T., Heltweg, B. et al. (2005),

'Substrate-specific activation of sirtuins by resveratrol', J. Biol. Chem. Vol. 280, pp. $17038-17045$

98. Mortimer, R.K. and Johnston, J.R. (1959), 'Life span of individual yeast cells', Nature Vol. 183, pp. 1751-1752.

99. Fabrizio, P. and Longo, V.D. (2003), 'The chronological life span of Saccharomyces cerevisiae', Aging Cell Vol. 2, pp. 73-81.

100. Kaeberlein, M. (2006), 'Longevity and aging in the budding yeast', in Conn, P.M., (Ed.), Handbook of models for human aging, Elsevier Academic Press, Boston, MA

101. Winzeler, E.A., Shoemaker, D.D., Astromoff, A. et al. (1999), 'Functional characterization of the $S$. cerevisiae genome by gene deletion and parallel analysis', Science Vol. 285, pp. 901-906. 